\title{
Short-term effects of thinning on the development and communities of understory vegetation of Chinese fir plantations in Southeastern China
}

\author{
Xuelei Xu ${ }^{1}$, Xinjie Wang ${ }^{1}$, Yang Hu ${ }^{1}$, Ping Wang ${ }^{2}$, Sajjad Saeed ${ }^{1}$, Yujun Sun ${ }^{\text {Corresp. } 1}$ \\ ${ }^{1}$ State Forestry Administration Key Laboratory of Forest Resources \& Environmental Management, Beijing Forestry University, Beijing, China \\ College of Grassland Science, Beijing Forestry University, Beijing, China \\ Corresponding Author: Yujun Sun \\ Email address: sunyj@bjfu.edu.cn
}

Background. High-density conditions are global issues that threaten the sustainable management of plantations throughout the world. Monocultures and untimely management practices have identically resulted in the simplex of community structures, decreases in biodiversity, and long-term productivity losses in plantations China. The most popular measure which is commonly used to address these issues is thinning, which potentially results in increases in the development of understory plants in plantations. However, there is limited information currently available regarding the community compositions of understory vegetation and the associated environmental factors, which has limited the sustainable management of China's fir plantation ecosystems.

Method. In the present study, a thinning experiment was implemented which included a control check (CK: no thinning), as well as low intensity thinning (LIT: 20\%), moderate intensity thinning (MIT: 33\%), and high intensity thinning (HIT: 50\%) in fir plantations located in the Southeastern China. During the investigation process, the understory vegetation examined three years after thinning measures were completed, in order to analyze the impacts of different thinning intensities on the growth and community compositions of the understory plants. At the same time, the associated environmental factors in the fir plantations were also investigated.

Results. The species richness, total coverage, and biomass of the understory vegetation were observed to be apparently increased with increasing thinning intensity. In addition, it was found that the thinning measures had prominently influenced the soil nutrients. The community compositions of the understory vegetation were significantly different among the four thinning intensity levels, especially between the $\mathrm{CK}$ and the HIT. Furthermore, the development of the understory vegetation was found to be significantly correlated with the soil nutrient contents, and the community compositions of the understory vegetation were prominently driven by the tree densities, slope positions, and soil nutrient contents. 
1 Short-term effects of thinning on the development and

2 communities of understory vegetation of Chinese fir

3 plantations in Southeastern China

4

5

6

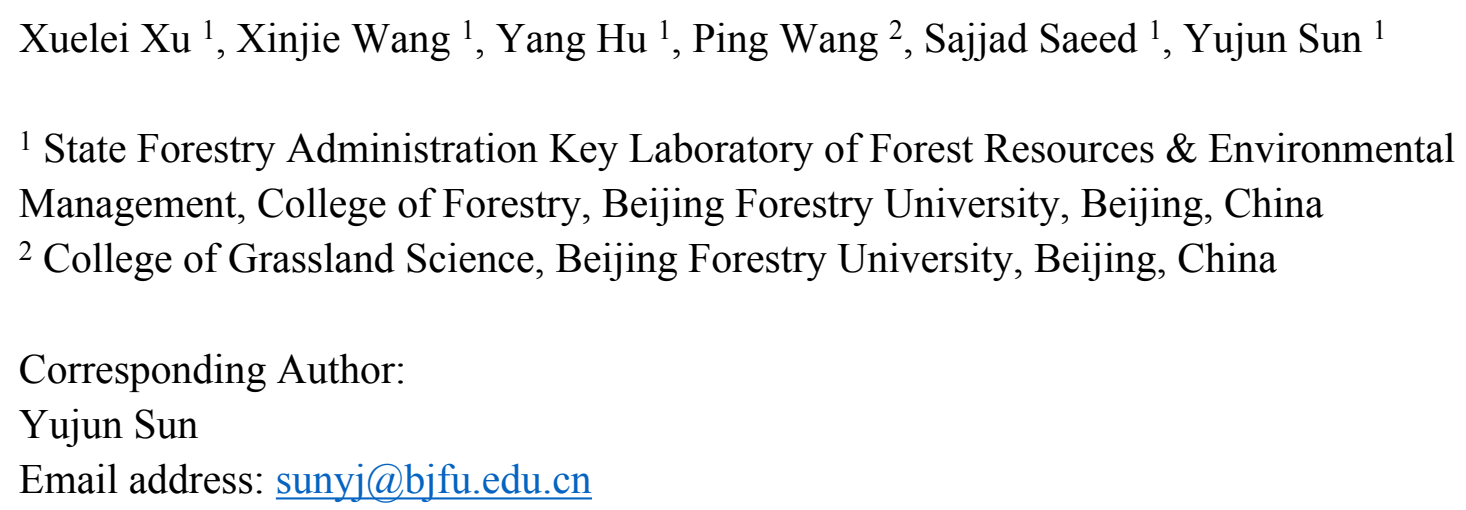

\section{Abstract}

Background. High-density conditions are global issues that threaten the sustainable management of plantations throughout the world. Monocultures and untimely management practices have identically resulted in the simplex of community structures, decreases in biodiversity, and long-term productivity losses in plantations China. The most popular measure which is commonly used to address these issues is thinning, which potentially results in increases in the development of understory plants in plantations. However, there is limited information currently available regarding the community compositions of understory vegetation and the associated environmental factors, which has limited the sustainable management of China's fir plantation ecosystems.

Method. In the present study, a thinning experiment was implemented which included a control check (CK: no thinning), as well as low intensity thinning (LIT: 20\%), moderate intensity thinning (MIT: 33\%), and high intensity thinning (HIT: 50\%) in fir plantations located in the Southeastern China. During the investigation process, the understory vegetation examined three years after thinning measures were completed, in order to analyze the impacts of different thinning intensities on the growth and community compositions of the understory plants. At the same time, the associated environmental factors in the fir plantations were also investigated. Results. The species richness, total coverage, and biomass of the understory vegetation were observed to be apparently increased with increasing thinning intensity. In addition, it was found that the thinning measures had prominently influenced the soil nutrients. The community compositions of the understory vegetation were significantly different among the four thinning intensity levels, especially between CK and HIT. Furthermore, the development of the understory vegetation was found to be significantly correlated with the soil nutrient contents, and 
the community compositions of the understory vegetation were prominently driven by the tree densities, slope positions, and soil nutrient contents.

\section{Introduction}

Over the past few decades, the Chinese government has extensively cultivated fast-growing trees in order to satisfy the increasing requirements for wood production (Zhou et al., 2016). It was estimated that the total area of tree plantations in China was approximately 69 million ha, which accounted for $24.64 \%$ of the global area (SFA, 2014; FAO, 2015). Chinese fir (Cunninghamia lanceolata) is an important tree species which has been widely planted in Southern China. It is known to be a type of fast-growing tree species, with high production levels and outstanding timber quality. It was estimated that the total area of Chinese fir plantations in China was approximately 8.95 million ha (SFA, 2014). However, it has been found that the stand volume and timber production have not been satisfactory, even though the areas of the plantations continue to increase (Sheng, 2018). This is due to the monocultures and high-density management practices which are in place at the present time (Tian et al., 2011). On one hand, the plantation forests, especially the pure coniferous plantations, were clearly recognized as having potential problems associated with monocultures, such as simplex community structures, low biodiversity, and a lack of biological stability (Savill et al., 1997). On the other hand, the majority of the plantations were initially planted with high densities and have not been efficiently managed (Lindgren \& Sullivan, 2013; Raunikar et al., 2010; Zhou et al., 2016), which has resulted in the poor development of understory vegetation, delays in litter decomposition, and losses in essential soil nutrients (Ma et al., 2007a; Sheng, 2001a; Tian et al., 2011). These issues have in turn brought lower long-term productivity and timber yields, and ultimately have seriously affected the sustainable management of the plantations (Ares et al., 2010; Sheng, 2001b; Wen et al., 2008). Therefore, the demand for emphasizing the development and community compositions of understory vegetation during forest management practice in China has not been effectively supported (Gilliam, 2007; Trentini et al., 2017).

At present, thinning measures have been recognized as a practical method to resolve the aforementioned problems in Chinese fir plantations (Sheng, 2001b). Thinning measures are the most popular silvicultural treatment throughout the world in plantation forests, and are extensively used to increase the growth of reserved trees, as well as improve the productivity levels of plantations (Trentini et al., 2017). In addition, this type of management method directly or indirectly influences the forest characteristics (Taki et al., 2010), such as the understory vegetation, soil properties, and even the microorganisms within the forest ecosystems themselves (Chen et al., 2015; Dang et al., 2018; Taki et al., 2010). It has been found that the implementation of thinning practices improved the growth spaces and light transmittance in stands by reducing the canopy densities, and ultimately enhanced the growth of both the reserved trees and understory plants (Ares et al., 2010; Cheng et al., 2013; Verschuyl et al., 2011). Previous studies have extensively surveyed the impacts of thinning on the diversity and biomass of understory vegetation (Cheng et al., 2014; Dang et al., 2018; Tamura \& Yamane, 2017; Wen 
et al., 2008), as well as the effects on tree growth rates (Gong et al., 2015; Wu et al., 2015), physical and chemical characteristics of the soil (Wang et al., 2013; Zhou et al., 2016), and even the soil microbial biomass (Kim et al., 2018; Thibodeau et al., 2000), nutrient transformations (Boerner et al., 2008), and soil respiration characteristics (Akburak \& Makineci, 2015; Tang et al., 2005).

The understory vegetation is an important part of forest ecosystems and plays critical roles in their structures and functions. For example, it has been found that healthy understory vegetation could effectively increase biodiversity, form or improve community structures, and enhance the stability of forest ecosystems (Baba et al., 2011; Harmer et al., 2016; Sheng, 2018; Yao et al., 1991). A growing number of forest managers and researchers have begun to focus on the importance of understory plants in plantation management processes (Torras \& Saura, 2008; Brunet et al., 2010; Trentini et al., 2017), in order to preserve the biodiversity and facilitate the formation and development of community structures, as well as maintain the various functions and long-term productivity of plantation ecosystems. Traditionally, various studies of thinning have provided inconsistent results on understory because focused on different tree species and conducted on different areas (Nagai \& Yoshida, 2006; Cheng et al., 2017; Lindh \& Muir, 2004). Particularly, some studies of thinning on Chinese fir plantations supported that the species richness, diversity, coverage and biomass of the understory plants increased with increasing thinning intensity (Xiong et al., 1995; Wang et al., 2010, 2019; Zhou et al., 2016). In contrary, another study showed that thinning have no effects on the diversity of understory in Chinese fir plantations (Cheng et al., 2014). The results of these previous studies have been far from universal and unified. In addition, a previous study demonstrated that plantation changed the community structures of understory compared with natural forests (Piwczyński et al., 2016). However, it remains unclear how thinning practices actually affect understory community structures and distribution patterns in plantation forest ecosystems.

Therefore, this study examined the responses of the diversity, coverage, biomass and community structures of understory vegetation to thinning and associated environmental factors in Chinese fir plantations located in Southeastern China, which is crucial to deepen the understanding of the effects of thinning on the basic processes of Chinese fir plantation ecosystems in order to guide the future management of such systems. We hypothesized that the thinning intensities would significantly affect the development and communities of the understory vegetation, which would be closely related to the modification of microclimates and alterations of edaphic factors. Therefore, in order to test this hypothesis, an experiment was conducted involving different thinning intensities to investigate the changing mechanisms of the understory vegetation in the study area. The specific aims were as follows: (1) to determine the effects of different thinning intensities on the diversity, coverage, and biomass of the understory vegetation; (2) to analyze the community compositions and distribution patterns of the understory vegetation impacted by the different thinning intensities; and (3) to identify the most important factors driving the community compositions and distribution patterns of the understory vegetation. 
117 Materials and methods

118

119

120

121

122

123

124

125

126

127

128

129

130

131

132

133

134

135

136

137

138

139

140

141

142

143

144

145

146

147

148

149

150

151

152

153

154

155

\section{Study area and site description}

This study area was located at Jiangle forest farm in Fujian Province of Southeastern China $\left(26^{\circ} 26^{\prime}-27^{\circ} 04^{\prime} \mathrm{N}, 117^{\circ} 05^{\prime}-117^{\circ} 40^{\prime} \mathrm{E}\right)$, with an elevation ranging between 200 and $800 \mathrm{~m}$ above sea level (Fig. 1). The climate in the study area was found to be subtropical monsoon climate. The mean annual temperature was determined to be $19.5^{\circ} \mathrm{C}$, and the mean annual precipitation was $1,665 \mathrm{~mm}$ (data from National Meteorological Information Center, observed from 1981 to 2010, http://data.cma.cn/site/index.html). This region was dominated by low-mountain hilly terrain. The soil in the study area was identified as ultisols (locally known as red clay soil) according to the USDA Soil Taxonomy (Li et al., 2019). The dominant tree species in the region included Chinese fir and Masson pine (Pinus massoniana). The prominent understory species included Callicarpa giraldii, Ficus hirta, Blechnum orientale, Stenoloma chusanum, Dicranopteris dichotoma, and Woodwardia japonica.

The study area was dominated by a Chinese fir forest which had first been planted in 2005 . The total area measured 3 ha and featured a similar site quality (Site index: $18 \mathrm{~m}$, base age of 20 years). The thinning experiments were initially established by Zhang (2015) in May of 2013 when the trees were eight years old. The experimental process included the following steps: firstly, after surveying the actual terrain and eliminating the edge effects, the study area was divided into four experimental sites measuring $100 \mathrm{~m} \times 30 \mathrm{~m}$, from upslope to the downward slope; Then, four thinning treatments were conducted in the four sites, which included a control check (CK: no thinning), a low intensity thinning (LIT: approximately 20\%), a moderate intensity thinning (MIT: approximately 33\%), and a high intensity thinning (HIT: approximately $50 \%$ ) (Ma et al., 2007b). Before thinning, the average diameter at breast height (DBH) and tree height were $12.83 \mathrm{~cm}$ and $8 \mathrm{~m}$, the average tree density was $2967 \mathrm{stems} \mathrm{ha}^{-1}$, the stand basal area was $38.00 \mathrm{~m}^{2} \mathrm{ha}^{-1}$, the stand volume was $198.07 \mathrm{~m}^{3} \mathrm{ha}^{-1}$. After thinning, the average DBH and tree height were $13.08 \mathrm{~cm}$ and $9.1 \mathrm{~m}$, the average residual density was from 1600 to 2967 stems $\mathrm{ha}^{-1}$, the stand basal area was $29.96 \mathrm{~m}^{2} \mathrm{ha}^{-1}$, the stand volume was $169.93 \mathrm{~m}^{3} \mathrm{ha}^{-1}$. Finally, three replicate plots were established at each thinned site in August of 2013. A total of 12 plots were established, and each plot was situated $5 \mathrm{~m}$ away from the next plot to minimize potential edge effects. The detailed information of the plots was shown in Table 1.

\section{Plots investigations}

The surveys of the understory vegetation were conducted in July of 2015 and 2016. The investigations of the understory vegetation were performed in five $5 \times 5 \mathrm{~m}$ subplots within each plot and five $1 \times 1 \mathrm{~m}$ quadrats within each subplot for the shrubs and herbs, respectively, at the center and each of the four corners of the study area. Initially, the species were identified according to the information obtained from the Chinese website eFlora of China (http://frps.iplant.cn) and Plant Photo Bank of China (http://ppbc.iplant.cn). The species, number, and coverage data of all the shrubs and herbs were investigated for the purpose of estimating the species richness and vegetative cover for this study's subsequent analyses. The species richness 
156

157

158

159

160

161

162

163

164

165

166

167

168

169

170

171

172

173

174

175

176

177

178

179

180

181

182

183

184

185

186

187

188

189

190

191

192

193

194

was defined as the number of species per plot (Widenfalk \& Weslien, 2009). The coverage was estimated as the ratio of the vertical projection of exposed leaf area to the area of each subplot. The average values of the vegetative cover in the five subplots effectively described the vegetation cover within each plot. Then, three of the five subplots (along the diagonal) were chosen to survey the understory biomass of each plot. All of the individuals were harvested (including roots) in each subplot and rapidly weighed to obtain the fresh weight data. The branches, leaves, and roots of the shrubs were distinguished, as well as the above- and belowground components of the herbs. At that point, all of the samples were oven-dried at $105^{\circ} \mathrm{C}$ until reaching a constant weight and subsequently used to estimate the biomass per hectare of each plot. The biomass was only investigated during the 2016 survey process, considering the destruction of the understory vegetation caused by the applied whole harvesting method.

Following the random selection of three soil sampling points within each plot, the physical properties of the soil were determined depending on the operational standards (State Forestry Bureau, 1999). In the present study, a soil cutting ring $\left(100 \mathrm{~cm}^{3}\right)$ was used at a depth of $20 \mathrm{~cm}$. The soil moisture content (SMC) was calculated according to the equation $\mathrm{SMC}=(\mathrm{Ww}-$ $\mathrm{Wd} / \mathrm{Wd} * 100 \%$, in which $\mathrm{Ww}$ represented the wet weight of the soil, and $\mathrm{Wd}$ indicated the dry weight of the soil (oven-dried at 105 to $110^{\circ} \mathrm{C}$ until reaching a constant weight). Furthermore, additional soil samples were collected from each sampling point at $0-20 \mathrm{~cm}$ soil layer using valve bags. These soil samples were divided into two parts: one was air-dried and sieved (less than $2 \mathrm{~mm}$ ) to measure the soil chemical properties according to the method described by Bao (2000), the other was stored at $4^{\circ} \mathrm{C}$ immediately for measurement of microbial biomass carbon $(\mathrm{MBC})$ and microbial biomass nitrogen $(\mathrm{MBN})$. In order to measure the soil $\mathrm{pH}$ values, the soil: water suspensions (1:5) were stirred for 30 minutes and then measured by a pH meter (LEICI, China). The soil organic carbon (SOC) was estimated by utilizing an elemental analyzer (FLASH2000 CHNS/O, USA). In addition, the soil total nitrogen (TN) and total phosphorus (TP) contents were determined using an AA3 continuous flow analytical system (AA3, Germany) after digesting with $\mathrm{HClO}_{4}-\mathrm{H}_{2} \mathrm{SO}_{4}$. The soil magnesium $(\mathrm{Mg})$ and manganese $(\mathrm{Mn})$ contents were measured using an atomic absorption spectrometer (TAS-990AFG, China) after digesting with $\mathrm{HNO}_{3}-\mathrm{HClO}_{4}$. The soil available nitrogen (AN) content was determined using an alkali solution diffusion method. The soil available phosphorus (AP) and available potassium (AK) contents were evaluated using spectrophotometry equipment (UV-2600, Japan) after HCl$\mathrm{NH}_{4} \mathrm{~F}$ extraction, and ammonium acetate extraction, respectively. $\mathrm{MBC}$ and $\mathrm{MBN}$ in the soil were estimated by adopting the fumigation-extraction method.

\section{Statistical analyses}

A one-way analysis of variance (ANOVA) method was adopted to assess the significant differences among the thinning intensities (four levels) on the characteristics of understory plants (species richness, coverage, and biomass), as well as the soil properties (SMC, $\mathrm{pH}, \mathrm{SOC}, \mathrm{TN}$, $\mathrm{TP}, \mathrm{AN}, \mathrm{AP}, \mathrm{AK}, \mathrm{Ca}, \mathrm{Mg}, \mathrm{Mn}, \mathrm{MBC}$, and MBN). The analysis of the significant differences in the multiple comparisons among the four thinning intensities was performed using Tukey's HSD 
test at $P<0.05$. A Pearson correlation analysis was used to detect the relationship between understory plant characteristics and soil properties.

The biodiversity indices (e.g. species richness) can quantify biodiversity and be comparable among different studies, but they place more emphasis on species counts rather than community structures and ecologically significant changes (Haughian \& Frego, 2016). In contrast, matrixbased dissimilarity assessment provides compositional changes than biodiversity indices. In the present study, a principal coordinate analysis (PCoA) with the Bray-Curtis dissimilarity measurement were adopted to elucidate the dissimilarities of the understory community compositions among the various plots (Oksanen et al., 2013). Furthermore, indicator species analysis (ISA) was adopted to evaluate the consistency and connection between species and treatments, i.e. such species refer to 'associates' rather than special 'indicators' (Haughian \& Frego, 2016).

This study included a canonical correspondence analysis (CCA) process, which was adopted to demonstrate the relationships between the environmental factors and understory species compositions, as well as to detect principal environmental factors impacting the understory structures. Before the CCA, a pre-selection of the explanatory variables was implemented using a Mantel test /Partial Mantel test method. In addition, a number of the variables were converted before being used in this study's analyses. The aspect was transformed from a $0^{\circ}$ to $360^{\circ}$ compass scale to a value between 0 and 1 (Yu \& Sun, 2013). The transformation was performed by the following formula:

\section{TRASP $=\{1-\cos [(\pi / 180) *($ aspect -30$)]\} / 2$}

The slope positions were converted to numerical values of 1,2 , and 3 , which represented lower, middle, and upper slopes, respectively. In addition, the correlations of the environmental factors showed that the correlation between the SOC and TN contents, AP and AN contents, and $\mathrm{Mg}$ and $\mathrm{Mn}$ contents of the soil were high. Therefore, these soil contents were merged into $\mathrm{C}$ and $\mathrm{N}$ content (SOILCN), available nutrient content (SOILA), and $\mathrm{Mg}$ and $\mathrm{Mn}$ content (SOILM), respectively. During the final analysis process, the species matrix contained the presence and absence data of the species. The environmental matrix contained 11 variables, namely tree density, slope position, SMC, SOILCN, TP, SOILA, AK, and SOILM.

The ANOVA results with multiple comparisons, as well as the figures, were finished via Origin 2019 software. The ISA was conducted with the function of 'indval' in R 3.3.3. Then, the PCoA and CCA were performed by the statistical package of 'vegan' in R 3.3.3.

\section{Results}

\section{Effects of thinning intensity on the soil and understory characteristics}

It was observed that the different thinning intensities had significantly influenced the SOC, $\mathrm{AP}$, and AK contents, with the highest content detected in the HIT of the tested soil samples, respectively (Table 2). The $\mathrm{SMC}, \mathrm{pH}, \mathrm{TN}, \mathrm{TP}, \mathrm{AN}, \mathrm{Mg}, \mathrm{Mn}, \mathrm{MBN}$, and $\mathrm{MBC}$ were found to be comparable among the four thinning intensities, without observable variations. 
The species richness, total coverage, and biomass of the understory vegetation were also found to be significantly influenced by the different thinning intensities, and both the shrubs and herbs had remarkably increased with the increasing thinning intensities. The highest values of species richness, total coverage, and biomass of the understory were detected in the HIT (Fig. 2).

\section{Relationships between the soil and the understory characteristics}

The species richness, total coverage, and biomass of the understory vegetation were found to be strongly correlated with the tree density, which confirmed that the intensities of the thinning process had significantly influenced the understory characteristics (Table 3 ). Furthermore, as can be seen in Table 3, it was also indicated that the understory characteristics were prominently positive relevant to the soil nutrients (for example, SOC, TN, TP, AP, and AK). However, such micro-topography factors as the aspect, slope, and slope position, as well as the soil Mg, Mn, MBC, and MBN contents, were not observed to be correlated with the understory vegetation characteristics.

\section{Effects of thinning intensity on the understory species compositions}

In the present study, 60 species of understory plants were discovered, including 31 shrub species belonging to 19 families and 24 genera, and 29 herb species belonging to 18 families and 24 genera. Among the 29 herb species, 24 species were ferns, accounting for $83 \%$ of the herbaceous species. The dominant shrub species were $C$. giraldii and $F$. hirta. The dominant herb species were Allantodia metteniana and $W$. japonica (Table S1). The ISA results identified one shrub species and five herb species which could be used as conspicuous indicators of the understory communities among the four thinning intensities. All of these species were identified as the indicators in HIT, as detailed in Table 4.

The PCoA results revealed significant changes in the understory community compositions among the four thinning intensities $(P=0.047)$. The ordination showed that the $\mathrm{CK}$ (no thinning) was separate from both the MIT (moderate) and HIT (high), while the LIT (low) and MIT (moderate) had clustered closely with each other (Fig. 3), which illustrated that understory communities were significantly different between CK and HIT.

\section{Relationships between the understory communities and the environmental factors}

The Mantel test results revealed that the understory species compositions were principally affected by the tree densities, slope positions, $\mathrm{C}$ and $\mathrm{N}$ contents of the soil, and the $\mathrm{Mg}$ and $\mathrm{Mn}$ contents of the soil, as illustrated in Table 5. The results of the canonical correspondence analysis (CCA) showed that these variables explained a total of $32.4 \%$ of the variation in the species distribution among plots, with Axis 1 explaining 17.4\% and Axis 2 explaining 15.0\% of the total variation (Fig. 4). The ordination plot revealed that the tree densities were the prominent factor which contributed to the understory community distributions among different thinning intensities, as well as SOILCN contributed to it among thinning intensities (Fig. 4). When controlling other environmental factors, slope position showed the strongest effect on understory community composition $(\mathrm{P}=0.001)$, while other soil nutrient contents ( $\mathrm{C}$ and $\mathrm{N}, \mathrm{Mg}$ and $\mathrm{Mn}$ ) showed less but significant influences (Table 5). 


\section{Discussion}

Our research highlighted that the thinning measures significantly improved the occurrence, growth rates, diversity and community formation of the understory vegetation, as well as the soil properties of Chinese fir plantations in Southeastern China. These results had great significance of the forest management in Chinese fir plantations. The responses of understory vegetation to thinning intensities were primarily associated with the canopy density and microenvironment in the stand.

In the present study, it was found that the species richness, coverage, and biomass of the undergrowing shrubs and herbs had increased significantly with the increasing thinning intensities (Fig. 2). These findings had supported this study's hypothesis. The results were not found to be surprising since it has been verified that thinning practices would potentially improve the spaces and light transmittance abilities in densely treed areas by reducing the canopy densities. As a result, the nutrient areas and growth spaces of the understory vegetation were enhanced (Sheng, 2001a; Ma et al., 2007a; Ares et al., 2010; Cañellas et al., 2004). Furthermore, the results obtained in this study were found to be in good agreement with those of previous related studies, in which thinning had enhanced the diversity, coverage, and biomass of undergrowth vegetation (Trentini et al., 2017; Zhou et al., 2016; Dang et al., 2018). For example, Zhou et al. (2016) investigated the understory vegetation of Chinese fir plantations in Southern China and found the biodiversity and biomass of the undergrowth vegetation had been significantly increased after pre-commercial thinning. This study's results further confirmed that the species richness, coverage, and biomass of the undergrowth vegetation significantly increased with the increasing of the thinning intensities. However, some of the previous related researches have suggested that thinning practices had little or negative impacts on undergrowth (Cheng et al., 2014, 2017). These contradictory results with regard to thinning effects on understory vegetation growth rates and biodiversity may have resulted from differences in forest stand circumstances, thinning intensities, plant community structures, and the stand ages of the forests (Brett \& Moniquee, 2009; Cheng et al., 2017; Juodvalkis et al., 2005). In the area examined in the present study, a high initial planting density had caused insufficient light transmittance to the undergrowth, as well as negatively affected the availability of soil nutrients for the understory vegetation. These factors may have led to the weak development of undergrowth vegetation (Sheng, 2001b). Therefore, when the undergrowth vegetation acquired enough light, nutrients, and growth space after thinning was implemented, the development of the understory plants had increased (Sheng, 2001b; Cheng et al., 2017).

The results obtained in this study also showed that thinning had significantly affected the SOC, AP, and AK contents in the study area, as detailed in Table 2. The results showed that thinning measures improved the soil nutrients contents, which was consistent with the results of the Dang et al (2018). In addition, the further analyses of the correlations between the understory vegetation and the soil properties indicated that the species richness, as well as the coverage and biomass of the understory vegetation, had significantly correlated with the soil nutrient contents, as illustrated in Table 3. On one hand, the improvements in light transmittance and temperature 
312 had resulted in higher decomposition rates after thinning. On the other hand, it was found that the 313 improved development of the understory plants after thinning had led to an increasing proportion 314 of rapidly decomposable litter, which could effectively supplement the available nutrient content 315 (for example, SOC, AN, AP, and AK) input to the soil (He \& Barclay, 2000; Teste et al., 2012; 316 Yao et al., 1991).

317 The results of this study indicated that the community compositions of the understory 318 vegetation had significantly differed among the four thinning intensities, and the variations 319 between the CK and HIT sections were most notable. Meanwhile, it was found that the LIT and which influenced the community compositions of the understory vegetation. Several previous related studies had indicated that the tree layers were important factors which also indirectly influenced the understory plants through the alteration of site factors such as litter mass and canopy openness (Brosofske et al., 2001; Wulf \& Naaf, 2009; Yu \& Sun, 2013). However, it was also indicated that the understory community similarity characteristics were high among the different thinning intensities, indicating that thinning does not necessarily influence the community compositions of the understory plants since there were no extreme changes in forest types and environments among the thinning intensities (He et al., 2019). In the present study, the significance of the tree density in the understory vegetation distributions suggested there were strong controls exerted on the understory communities by the different thinning intensities. The variations of the understory community compositions among the four examined thinning intensities were found to be caused by changes in the light transmittance within the forest, which is beneficial to the growth of some light-demanding species (Cañellas et al., 2004). That is, there might be only a small number of shade-tolerant understory species in the un-thinned stands, which led to a very simple understory species composition. However, most pre-established species increased as the canopy thinning, especially light-favoring pioneer species.

Subsequently, the forest had formed multi-storied communities due to the reductions in both tree densities and light deficiency (Zhou et al., 2016). Some light-demanding species were identified as significant indicators in the HIT section, such as C. giraldii, P. glanduligera, and A. japonica.

It was also determined by this study's results that the soil properties were demonstrated as the primary factors affecting the community compositions of understory vegetation among all of the different thinning intensities (Fig. 4; Table 5). Previous studies had illustrated the soil nutrient contents were important factors which influenced the community compositions of the understory vegetation (Ploughe \& Dukes, 2019; Zarfos et al., 2019). For example, Zarfos et al. (2019) demonstrated that the community compositions displayed significant changes with different gradients of soil acidity, base cation availability, and carbon-to-nitrogen ratios $(\mathrm{C}: \mathrm{N})$. Furthermore, Legare et al. (2001) found that the canopy types affected the understory compositions through impacting nutrient availability. However, other related studies had reflected that the levels of soil fertility did not play significant roles in the characteristics of understory communities (Yu \& Sun, 2013). In the current study, it was determined that the soil C and $\mathrm{N}$ content (inferred by the data of the soil organic carbon and nitrogen) and soil $\mathrm{Mg}$ and $\mathrm{Mn}$ 
contents had appeared to play significant roles in the understory community characteristics in the study area.

Most importantly, it was unexpectedly found that slope position was an important topographical factor contributed to community compositions of understory vegetation (Fig. 4; Table 5). Favorable positions were determined to be the primary drivers of the observed differences in community compositions of understory vegetation among the different thinning intensities. Generally speaking, on such small scales as stands and communities, the overstory structural, topographical, and edaphic factors were generally considered to be the primary drivers of the observed differences in understory community compositions (Van Couwenberghe et al., 2010; Siefert et al., 2012). Slope position, as an important topographical factor, determined the heterogeneity of the microenvironment of the local habitat through controlling such conditions as light, temperature, and moisture in the forest (Liang et al., 2017), and thereby affected soil structure and development (Seibert et al., 2007; Mohammadi et al., 2016), soil nutrients redistribution and availability by gravity and hydraulic power (Fisk et al., 1998; Xiao et al., 2019). As a result, slope position would influence the growth, diversity, distribution, and community composition of vegetation (Zhou et al., 2009; Zhang et al., 2011; Lei et al., 2018). Previous studies have shown that topographical factors play a part in determining the differences in the community compositions of understory vegetation (Dai et al., 2010; Yang et al., 2005, 2006; Zhang et al., 2011). These topographical factors include altitude gradient (Coll et al., 2011; Saima et al., 2018) and aspect (Bennie et al., 2006; Yu \& Sun, 2013; Yu et al., 2013). In this study, the slope positions were detected as the most significantly topographical factor affecting the community compositions of the understory vegetation, which had been rarely mentioned in previous related studies. Our study area is located in the hilly areas of Southern China, where the topography is heterogeneous, and thereby the micro-topographic factors, such as slope position, may strongly affect the ecological environments of the local habitat, as well as the soil and vegetation. Therefore, our results were instructive for forestry researchers to understand that slope position should be considered in the management and further researches of such plantation ecosystems.

Although this study was conducted in a short-term (three years) after thinning, the results were instructive for forestry researchers and managers to understand the effects of the different thinning intensities on the development and community compositions of the understory vegetation, which provided a clear understanding of the mechanisms of thinning management for Chinese fir plantations in Southeastern China, and suggested that high intensity thinning could potentially improve the development of the understory plants. In addition, it can be expected that in other forest ecosystems with high stand density in the world, reasonable thinning measures could improve the development of understory vegetation, increase the biodiversity, coverage and biomass of undergrowth, and promote community formation of understory plants, which enhance the productivity and sustainable management of forests. Furthermore, in order to objectively assess the effects of thinning intensities on the understory vegetation, and provide more reliable long-term forest management measures, it is recommended that future studies should focus on 
392 long-term continuous observations and the analysis of any observed dynamic changes which may 393 occur over time.

\section{Conclusions}

The results of this study strongly indicated that the thinning of Chinese fir plantations significantly influenced the development, diversity, and community compositions of the understory vegetation of Chinese fir plantations in this study area, as well as the properties of the soil. The species richness, total coverage, and biomass of the understory plants were observed to significantly increase with the increasing thinning intensities. It was also found that thinning measures had prominently influenced the soil nutrients (for example, SOC, AP, and AK). The community compositions of the understory vegetation were observed to be significantly different among four thinning intensities. This was found to be especially obvious between CK (control) and HIT (high intensity). In addition, the growth of the understory vegetation was significantly correlated with the soil nutrient contents (for example, SOC, TN, TP, AP, and AK), and the community compositions of the understory vegetation were prominently driven by tree densities, slope positions, soil $\mathrm{C}$ and $\mathrm{N}$ contents, and soil $\mathrm{Mg}$ and $\mathrm{Mn}$ contents. These findings suggested that high intensity thinning (approximately 50\%) should be conducted in Chinese fir plantations, which could potentially improve the development of the understory plants of Chinese fir plantations in Southeastern China and expected in other forest ecosystems with high stand density in the world.

\section{Acknowledgements}

We acknowledge all those who involved for the hard work in field data collection and who helped us in writing the paper: Yujun Sun and Xinjie Wang guided the experiment, oversaw the entire statistical analysis and suggested improvements; Yang Hu and Sajjad Saeed reviewed the articles and suggested improvements; and Ping Wang guided the data analysis. We appreciate Peng Zhang who established the thinning experiments. We also acknowledge the use of the facilities at the Centre Experiment and Teaching, College of Forestry, Beijing Forestry University.

\section{References}

Akburak S, and Makineci E. 2015. Effects of thinning on soil respiration and microbial respiration of forest floor and soil in an oak (Quercus frainetto) forest. Soil Research 53(5):522-530.

Ares A, Neill AR, and Puettmann KJ. 2010. Understory abundance, species diversity and functional attribute response to thinning in Coniferous stands. Forest Ecology and Management 260(7):1104-1113.

Baba M, Abe S, Kasai M, Sugiura T, and Kobayashi H. 2011. Contribution of understory vegetation to minimizing nitrate leaching in a Japanese cedar plantation. Journal of Forest Research 16(6):446-455.

Bao S. 2000. Soil and Agricultural Chemistry Analysis. China Agriculture Press: Beijing.

Bennie J, Hill MO, Baxter R, and Huntley B. 2006. Influence of slope and aspect on long-term vegetation change 
429 in British Chalk Grasslands. Journal of Ecology 94(2):355-368.

430 Boerner REJ, Giai C, Huang JJ, and Miesel JR. 2008. Initial effects of fire and mechanical thinning on soil enzyme activity and nitrogen transformations in eight North American forest ecosystems. Soil Biology \& Biochemistry 40(12):3076-3085.

Brett W, and Moniquee R. 2009. Thinning and chipping small-diameter ponderosa pine changes understory plant communities on the Colorado Front Range. Forest Ecology and Management 257(1):85-95.

Brosofske KD, Chen J, and Crow TR. 2001. Understory vegetation and site factors: implications for a managed Wisconsin landscape. Forest Ecology and Management 146(1-3):75-87.

Brunet J, Fritz Ö, and Richnau G. 2010. Biodiversity in European beech forests - a review with recommendations for sustainable forest management. Ecological Bulletins 53:77-94.

Cañellas I, Río MD, Roig S, and Montero G. 2004. Growth response to thinning in Quercus pyrenaica Willd. coppice stands in Spanish central mountain. Annals of Forest Science 61(3):243-250.

Chen XL, Wang D, Chen X, Wang J, Diao JJ, Zhang JY, and Guan QW. 2015. Soil microbial functional diversity and biomass as affected by different thinning intensities in a Chinese fir plantation. Applied Soil Ecology 92:35-44.

Cheng CP, Wang YD, Fu XL, Xu MJ, Dai XQ, and Wang HM. 2017. Thinning effect on understory community and photosynthetic characteristics in a subtropical Pinus massoniana plantation. Canadian Journal of Forest Research 47(8):1104-1115.

Cheng XR, Xu JL, Liu J, and Yu MK. 2014. Effect of thinning on understory vegetation diversity and its nutrient stocks in Cunninghamia lanceolata plantation. Ecology and Environmental Sciences 23(1):30-34.

Cheng XR, Yu MK, and Wu TG. 2013. Effect of forest structural change on carbon storage in a coastal Metasequoia glyptostroboides stand. The Scientific World Journal 2013(5):830509.

Coll L, Gonzalez-Olabarria JR, Mola-Yudego B, Pukkala T, and Messier C. 2011. Predicting understory maximum shrubs cover using altitude and overstory basal area in different Mediterranean forests. European Journal of Forest Research 130(1):55-65.

Dai N, Hirabuki Y, and Mochida Y. 2010. Influence of micro-landforms on forest structure, tree death and recruitment in a Japanese temperate mixed forest. Ecological Research 18(5):533-547.

Dang P, Gao Y, Liu JL, Yu SC, and Zhao Z. 2018. Effects of thinning intensity on understory vegetation and soil microbial communities of a mature Chinese pine plantation in the Loess Plateau. Science of the Total Environment 630: $171-180$.

FAO (Food and Agriculture Organization of the United Nations). 2015. Global forest resources assessment 2015: Main report.

Fisk MC, Schmidt SK, and Seastedt TR. 1998. Topographic patterns of above- and belowground production and nitrogen cycling in alpine tundra. Ecology 7(79):2253-2266.

Gilliam FS. 2007. The ecological significance of the herbaceous layer in temperate forest ecosystems. Bioscience 57(10):845-858.

Gong GT, Niu M, and Mu CL. 2015. Impacts of different thinning intensities on growth of Cupressus funebris plantation and understory plants. Scientia Silvae Sinicae 51(04):8-15.

Harmer R, Kerr G, Stokes V, and Connolly T. 2016. The influence of thinning intensity and bramble control on ground flora development in a mixed broadleaved woodland. Forestry 90(2):247-257. 
468 Haughian SR, and Frego KA. 2016. Short-term effects of three commercial thinning treatments on diversity of understory vascular plants in white spruce plantations of northern New Brunswick. Forest Ecology and Management 370:45-55.

He FL, and Barclay HJ. 2000. Long-term response of understory plant species to thinning and fertilization in a Douglas-fir plantation on southern Vancouver Island, British Columbia. Canadian Journal of Forest Research 30(4):566-572.

He H, Zhang Z, Zhang C, Hao M, Yao J, Xie Z, Gao H, and Zhao X. 2019. Short-term effects of thinning intensity on stand growth and species diversity of mixed coniferous and broad-leaved forest in northeastern China. Scientia Silvae Sinicae 55(2):1-12.

Juodvalkis A, Kairiukstis L, and Vasiliauskas R. 2005. Effects of thinning on growth of six tree species in northtemperate forests of Lithuania. European Journal of Forest Research 124(3):187-192.

Kim S, Li GL, Han SH, Kim HJ, Kim C, Lee ST, and Son Y. 2018. Thinning affects microbial biomass without changing enzyme activity in the soil of Pinus densiflora Sieb. et Zucc. forests after 7 years. Annals of Forest Science 75(1):1-10.

Legare S, Bergeron Y, Leduc A, and Pare D. 2001. Comparison of the understory vegetation in boreal forest types of southwest Quebec. Canadian Journal of Botany-revue Canadienne de Botanique 79(9):1019-1027.

Lei SY, Zhao WH, Yang YH, Lv D, Bai YB, He L, Guo JW, and Zhang XP. 2018. Spatial Distribution Characteristics of Soil Nutrients and Vegetation Growth Status in Different Slopes. Research of Soil and Water Conservation 26(1):1-7.

Li L, McCormack ML, Chen F, Wang H, Ma Z, and Guo D. 2019. Different responses of absorptive roots and arbuscular mycorrhizal fungi to fertilization provide diverse nutrient acquisition strategies in Chinese fir. Forest Ecology and Management 433:64-72.

Liang Y, Su Y, He X, Chen X, and Hu Y. 2017. Various effects on the Abundance and Composition of Arbuscular Mycorrhizal Fungal Communities in Soils in Karst Shrub Ecosystems. Environmental Science 38(11):4828-4835.

Lindgren PMF, and Sullivan TP. 2013. Influence of stand thinning and repeated fertilization on plant community abundance and diversity in young lodgepole pine stands: 15-year results. Forest Ecology and Management 308:1730.

Lindh BC, and Muir PS. 2004. Understory vegetation in young Douglas-fir forests: does thinning help restore oldgrowth composition? Forest Ecology and Management 192(2-3):285-296.

Ma LY, Li CY, and Wang XQ. 2007. Effects of thinning on the growth and the diversity of undergrowth of Pinus tabulaeformis plantation in Beijing mountainous areas. Scientia Silvae Sinicae 43(05):1-9.

Ma XQ, Heal KV, Liu A, and Jarvis PG. 2007. Nutrient cycling and distribution in different-aged plantations of Chinese fir in southern China. Forest Ecology and Management 243(1):61-74.

Mohammadi MF, Jalali SGH, Kooch Y, and Said-Pullicino D. 2016. Slope gradient and shape effects on soil profiles in the northern mountainous forests of Iran. Eurasian Soil Science 49(12):1366-1374.

Nagai M, and Yoshida T. 2006. Variation in understory structure and plant species diversity influenced by silvicultural treatments among 21- to 26-year-old Picea glehnii plantations. Journal of Forest Research 11(1):1-10.

Oksanen J, Blanchet FG, Kindt R, Legendre P, Minchin PR, O'Hara RB, Simpson GL, Solymos P, Stevens МHH, and Wagner H. 2013. Vegan: Community ecology package. Available at http://CRAN.R- 
project.org/package=vegan .

Piwczyński M, Puchałka R, and Ulrich W. 2016. Influence of tree plantations on the phylogenetic structure of understorey plant communities. Forest Ecology and Management 376:231-237.

Ploughe LW, and Dukes JS. 2019. Understory plant composition and nitrogen transformations resistant to changes in seasonal precipitation. Ecosphere 10(5): $\mathrm{e} 02747$.

Raunikar R, Buongiorno J, Turner JA, Zhu SS, and Perezgarcia J. 2010. Global outlook for wood and forests with the bioenergy demand implied by scenarios of the Intergovernmental Panel on Climate Change. Forest Policy and Economics 12(1):48-56.

Saima S, Altaf A, Faiz MH, Shahnaz F, and Wu G. 2018. Vegetation patterns and composition of mixed coniferous forests along an altitudinal gradient in the Western Himalayas of Pakistan. Austrian Journal of Forest Science 135(2):159-180.

Savill P, Evans J, Auclair D, and Falck J. 1997. Plantation Silviculture in Europe. Oxford university press: Oxford. Seibert J, Stendahl J, and Sørensen R. 2007. Topographical influences on soil properties in boreal forests. Geoderma 141(1-2):139-148.

SFA (State Forestry Administration of Forest Resources Management). 2014. The 8th national forest resources inventory and the status of forest resources. Forest Resources Management.

Sheng WT. 2001a. A long-term study on development and succession of undergrowth vegetation in Chinese fir (Cunninghamia lanceolata) plantations with different density. Forest Research 5(14):463-471.

Sheng WT. 2001b. Studies on density management and long-term productivity of Cunninghamia lanceolata forests. Scientia Silvae Sinicae 37(5):2-9.

Sheng WT. 2018. On the maintenance of long-term productivity of plantation in China. Forest Research 1(31):1-14. Siefert A, Ravenscroft C, Althoff D, Alvarez-Yépiz JC, Carter BE, Glennon KL, Heberling JM, Jo IS, Pontes A, Sauer A, Willis A, and Fridley JD. 2012. Scale dependence of vegetation-environment relationships: a metaanalysis of multivariate data. Journal of Vegetation Science 23(5):942-951.

State Forestry Bureau. 1999. The forestry operation standard of the People's Republic of China-forest soil moisture - physical properties measurement. LY/T 1215-1999. China Standards Press: Beijing.

Taki H, Inoue T, Tanaka H, Makihara H, Sueyoshi M, Isono M, and Okabe K. 2010. Responses of community structure, diversity, and abundance of understory plants and insect assemblages to thinning in plantations. Forest Ecology and Management 259(3):607-613.

Tamura A, and Yamane M. 2017. Response of understory vegetation over 10 years after thinning in an old-growth cedar and cypress plantation overgrazed by sika deer in eastern Japan. Forest Ecosystems 4(1):1-10.

Tang J, Qi Y, Xu M, Misson L, and Goldstein AH. 2005. Forest thinning and soil respiration in a ponderosa pine plantation in the Sierra Nevada. Tree Physiology 25(1):57-66.

Teste FP, Lieffers VJ, and Strelkov SE. 2012. Ectomycorrhizal community responses to intensive forest management: thinning alters impacts of fertilization. Plant and Soil 360(1-2):333-347.

Thibodeau L, Raymond P, Camiré C, and Munson AD. 2000. Impact of precommercial thinning in balsam fir stands on soil nitrogen dynamics, microbial biomass, decomposition, and foliar nutrition. Canadian Journal of Forest Research 30(2):229-238.

Tian DL, Xiang WH, Chen XH, Yan WD, Fang X, Kang WX, Dan XW, Peng CH, and Peng YY. 2011. A long- 
546 term evaluation of biomass production in first and second rotations of Chinese fir plantations at the same site. Forestry 547 84(4):411-418.

548 Torras O, and Saura S. 2008. Effects of silvicultural treatments on forest biodiversity indicators in the Mediterranean. Forest Ecology and Management 255(8-9):3322-3330.

Trentini CP, Campanello PI, Villagra M, Ritter L, Ares A, and Goldstein G. 2017. Thinning of loblolly pine plantations in subtropical Argentina: Impact on microclimate and understory vegetation. Forest Ecology and Management 384:236-247.

Van Couwenberghe R, Collet C, Lacombe E, Pierrat J, and Gégout J. 2010. Gap partitioning among temperate tree species across a regional soil gradient in windstorm-disturbed forests. Forest Ecology and Management 260(1):146-154.

Verschuyl J, Riffell S, Miller D, and Wigley TB. 2011. Biodiversity response to intensive biomass production from forest thinning in North American forests - A meta-analysis. Forest Ecology and Management 261(2):221-232.

Wang D, Olatunji OA, and Xiao J. 2019. Thinning increased fine root production, biomass, turnover rate and understory vegetation yield in a Chinese fir plantation. Forest Ecology and Management 440:92-100.

Wang K, Ma LY, Jia ZK, and Wang W. 2013. Short-term responses of undergrowth of Pinus tabuliformis plantation at different standages to different thinning intensity. Journal of Northeast Forestry University 41(10):1-9.

Wang ZH, Li RX, and Wang XJ. 2010. Effects of thinning on understory species diversities and biomass of Cunninghamia lanceolata forests. Ecology and Environmental Sciences 19(12):2778-2782.

Wen YG, Cheng F, and Liu SR. 2008. Relationship between species diversity and biomass of Eucalyptus plantation in Guangxi. Scientia Silvae Sinicae 44(4):14-19.

Widenfalk O, and Weslien J. 2009. Plant species richness in managed boreal forests-Effects of stand succession and thinning. Forest Ecology and Management 257(5):1386-1394.

Wu JQ, Wang YX, Yang Y, and Zhu TT. 2015. Effect of crop tree release on stand growth and stand structure of Cunninghamia lanceolata plantation. Journal of Applied Ecology 26(2):340-348.

Wulf M, and Naaf T. 2009. Herb layer response to broadleaf tree species with different leaf litter quality and canopy structure in temperate forests. Journal of Vegetation Science 20(3):517-526.

Xiao Y, Yang L, Nie X, Li C, Xiong F, Wang L, and Zhou G. 2019. Effects of slope position on phylogenetic diversity and community structure of alpine shrub community. Chinese Journal of Ecology 38(6):1611-1619.

Xiong YQ, Sheng WT, and Zeng MS. 1995. Study on the development and biomass of understory vesetation under different thinning intensities in Chinese fir platantions. Forest Research 8(4):408-413.

Yang YC, Da LJ, and You WH. 2005. Vegetation structure in relation to micro-landform in Tiantong National Forest Park, Zhejiang, China. Acta Ecologica Sinica 25(11):2830-2840.

Yang YC, and Da LJ. 2006. A brief review for studies on differentiation of vegetation pattern along a topographic gradient in hilly regions. Journal of Plant Ecology 30(3):504-513.

Yao MH, Sheng WT, and Xiong YQ. 1991. Study on the influence of undergrowth vegetation on the soil fertility of Chinese fir. Forest Research 3(4):247-251.

Yu M, Zhou ZY, Kang FF, Ouyang S, Mi XC, and Sun JX. 2013. Gradient analysis and environmental interpretation of understory herb-layer communities in Xiaoshegou of Lingkong Mountain, Shanxi, China. Chinese Journal of Plant Ecology 37(5):373-383. 
585 Yu M, and Sun OJ. 2013. Effects of forest patch type and site on herb-layer vegetation in a temperate forest 586 ecosystem. Forest Ecology and Management 300:14-20.

587 Zarfos MR, Dovciak M, Lawrence GB, McDonnell TC, and Sullivan TJ. 2019. Plant richness and composition in 588 hardwood forest understories vary along an acidic deposition and soil-chemical gradient in the northeastern United 589 States. Plant and Soil 438(1-2):461-477.

590 Zhang P. 2015. A study of Chinese fir plantation forest structure and growth on different density control. Beijing 591 Forestry University.

592 Zhang Q, Niu J, Buyantuyev A, Han F, Dong J, Zhang Y, Kang S, and Yang Y. 2011. Vegetation differentiation 593 and soil effect at different slope locations - a case study of Stipa breviflora grassland in Inner Mongolia, China. 594 Chinese Journal of Plant Ecology 35(11):1167-1181.

595 Zhou LL, Cai LP, He ZM, Wang RW, Wu PF, and Ma XQ. 2016. Thinning increases understory diversity and 596 biomass, and improves soil properties without decreasing growth of Chinese fir in southern China. Environmental 597 Science and Pollution Research 23(23):24135-24150.

598 Zhou P, Liu G, and Hou X. 2009. Biomass and species diversity of herbosa at different position and aspects of slope 599 in the Hilly-gully Region of Loess Platea. Science of Soil and Water Conservation 7(01):67-73.

600 
Figure 1

Locations of the study area and sample plots.

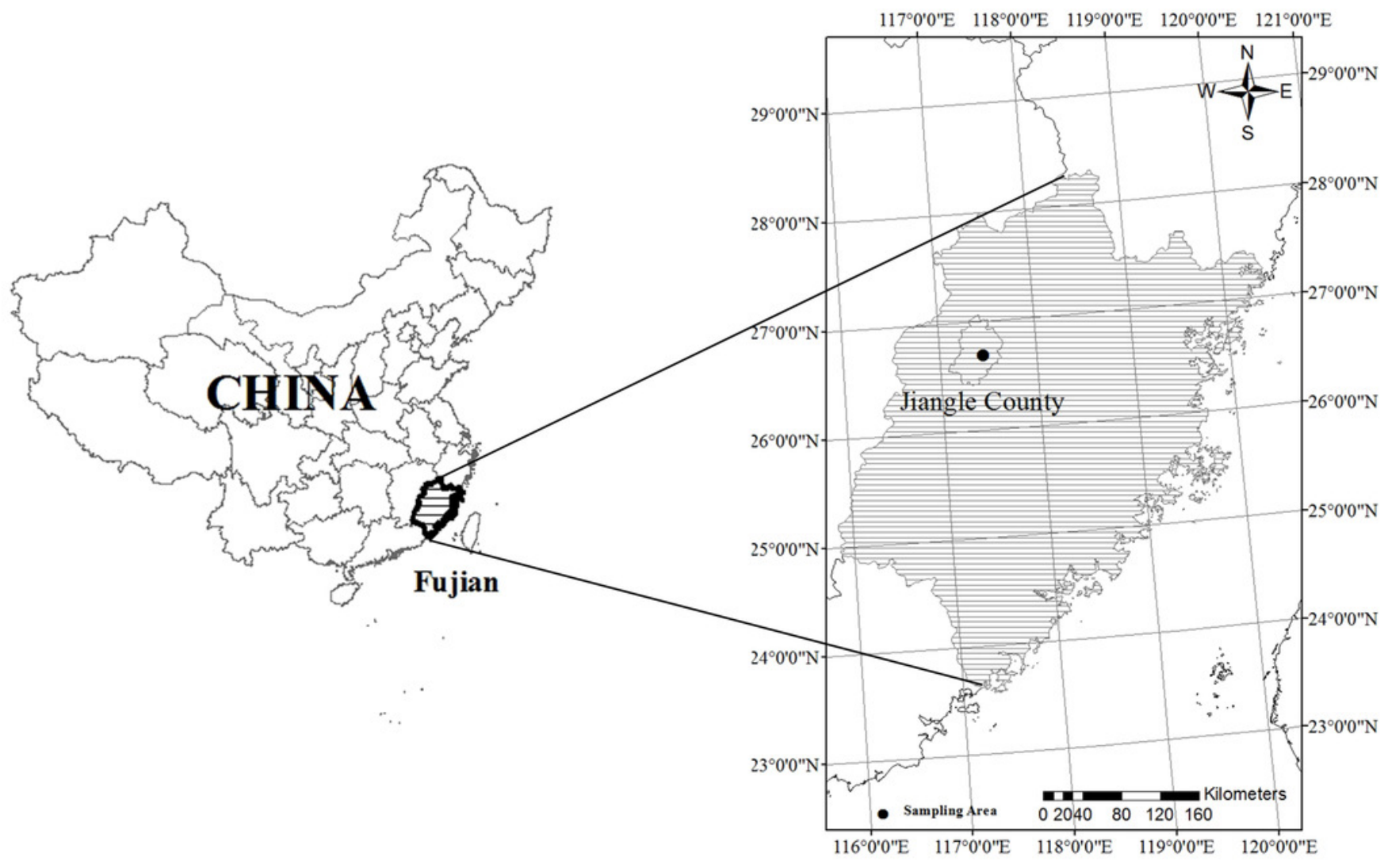




\section{Table $\mathbf{1}$ (on next page)}

Basic conditions of the sample plots. 


\begin{tabular}{cccccccccc}
\hline Plots & $\begin{array}{c}\text { Area of } \\
\text { plots } \\
\left(\mathrm{m}^{2}\right)\end{array}$ & Aspect & Slope & $\begin{array}{c}\text { Altitude } \\
(\mathrm{m})\end{array}$ & $\begin{array}{c}\text { Number } \\
\text { of tree } \\
(\text { Stem })\end{array}$ & $\begin{array}{c}\text { Reserved } \\
\text { tree density } \\
\left(\text { Stem ha }^{-1}\right)\end{array}$ & $\begin{array}{c}\text { Mean } \\
\text { DBH } \\
(\mathrm{cm})\end{array}$ & $\begin{array}{c}\text { Mean tree } \\
\text { height }(\mathrm{m})\end{array}$ & $\begin{array}{c}\text { Canopy } \\
\text { density } \\
(\%)\end{array}$ \\
\hline CK1 & $15 \times 20$ & $311^{\circ}$ & $32^{\circ}$ & 246.5 & 87 & 2900 & 11.8 & 10.0 & 88 \\
CK2 & $15 \times 20$ & $310^{\circ}$ & $31^{\circ}$ & 221.8 & 88 & 2933 & 12.8 & 9.9 & 89 \\
CK3 & $15 \times 20$ & $303^{\circ}$ & $34^{\circ}$ & 206.3 & 92 & 3067 & 13.2 & 9.0 & 90 \\
LIT1 & $15 \times 20$ & $304^{\circ}$ & $35^{\circ}$ & 249.8 & 74 & 2467 & 13.3 & 9.6 & 74 \\
LIT2 & $15 \times 20$ & $346^{\circ}$ & $32^{\circ}$ & 235.4 & 75 & 2500 & 12.2 & 8.8 & 73 \\
LIT3 & $20 \times 20$ & $292^{\circ}$ & $31^{\circ}$ & 215.9 & 95 & 2375 & 13.2 & 8.2 & 70 \\
MIT1 & $15 \times 20$ & $295^{\circ}$ & $30^{\circ}$ & 258.2 & 58 & 1933 & 14.0 & 8.8 & 58 \\
MIT2 & $15 \times 20$ & $300^{\circ}$ & $33^{\circ}$ & 239.6 & 61 & 2033 & 12.9 & 9.4 & 65 \\
MIT3 & $20 \times 20$ & $296^{\circ}$ & $33^{\circ}$ & 215.2 & 85 & 2125 & 13.6 & 9.9 & 65 \\
HIT1 & $15 \times 20$ & $296^{\circ}$ & $31^{\circ}$ & 262.1 & 45 & 1500 & 12.1 & 8.5 & 50 \\
HIT2 & $15 \times 20$ & $303^{\circ}$ & $39^{\circ}$ & 238.5 & 50 & 1667 & 13.4 & 8.5 & 52 \\
HIT3 & $15 \times 20$ & $318^{\circ}$ & $31^{\circ}$ & 215.4 & 49 & 1633 & 13.1 & 7.9 & 50 \\
\hline
\end{tabular}


Table 2 (on next page)

Soil properties among four thinning intensities of Chinese fir plantations. 


\begin{tabular}{|c|c|c|c|c|c|c|}
\hline Variations & CK & LIT & MIT & HIT & $F$ & $P$ \\
\hline SMC (\%) & $29.51 \pm 4.64$ & $30.36 \pm 4.73$ & $31.57 \pm 5.30$ & $34.19 \pm 7.47$ & 0.13 & 0.939 \\
\hline $\mathrm{pH}$ & $4.40 \pm 0.12$ & $4.37 \pm 0.08$ & $4.34 \pm 0.05$ & $4.43 \pm 0.09$ & 0.18 & 0.906 \\
\hline $\operatorname{SOC}\left(\mathrm{g} \mathrm{kg}^{-1}\right)$ & $20.71 \pm 1.68 b$ & $35.06 \pm 1.43 \mathrm{ab}$ & $29.59 \pm 3.77 \mathrm{ab}$ & $42.84 \pm 6.17 \mathrm{a}$ & 6.07 & $0.019 *$ \\
\hline $\mathrm{TN}\left(\mathrm{g} \mathrm{kg}^{-1}\right)$ & $0.12 \pm 0.02$ & $0.21 \pm 0.02$ & $0.19 \pm 0.03$ & $0.28 \pm 0.06$ & 2.95 & 0.098 \\
\hline TP $\left(\mathrm{g} \mathrm{kg}^{-1}\right)$ & $0.32 \pm 0.01$ & $0.32 \pm 0.02$ & $0.30 \pm 0.01$ & $0.35 \pm 0.01$ & 1.52 & 0.282 \\
\hline $\mathrm{AN}\left(\mathrm{mg} \mathrm{kg}^{-1}\right)$ & $118.72 \pm 15.28$ & $171.11 \pm 16.62$ & $146.74 \pm 8.26$ & $162.33 \pm 20.73$ & 2.10 & 0.179 \\
\hline $\mathrm{AP}\left(\mathrm{mg} \mathrm{kg}^{-1}\right)$ & $1.80 \pm 0.28 b$ & $3.79 \pm 0.52 \mathrm{ab}$ & $3.51 \pm 0.25 \mathrm{ab}$ & $4.73 \pm 0.63 \mathrm{a}$ & 7.33 & $0.011 *$ \\
\hline $\mathrm{AK}\left(\mathrm{mg} \mathrm{kg}^{-1}\right)$ & $58.09 \pm 3.83 \mathrm{ab}$ & $51.48 \pm 3.37 \mathrm{~b}$ & $47.87 \pm 3.57 b$ & $70.44 \pm 3.11 \mathrm{a}$ & 8.14 & $0.008^{* *}$ \\
\hline $\operatorname{Mg}\left(\mathrm{mg} \mathrm{kg}^{-1}\right)$ & $69.19 \pm 6.61$ & $80.07 \pm 6.84$ & $73.18 \pm 7.14$ & $74.20 \pm 9.16$ & 0.36 & 0.785 \\
\hline $\operatorname{Mn}\left(\mathrm{mg} \mathrm{kg}^{-1}\right)$ & $85.65 \pm 21.63$ & $122.46 \pm 39.55$ & $88.09 \pm 23.95$ & $121.19 \pm 24.60$ & 0.51 & 0.687 \\
\hline $\operatorname{MBC}\left(\mathrm{mg} \mathrm{kg}^{-1}\right)$ & $121.07 \pm 34.33$ & $166.17 \pm 67.15$ & $221.67 \pm 31.47$ & $149.70 \pm 46.71$ & 0.81 & 0.524 \\
\hline $\operatorname{MBN}\left(\mathrm{mg} \mathrm{kg}^{-1}\right)$ & $41.33 \pm 5.26$ & $32.70 \pm 2.22$ & $35.80 \pm 10.25$ & $95.80 \pm 42.11$ & 1.86 & 0.215 \\
\hline
\end{tabular}

1 Note: Values are mean \pm stand error; ${ }^{*}$ indicates $P<0.05 ;{ }^{* *}$ indicates $P<0.01$; and ${ }^{* * *}$ indicates $P<0.001$; Different

2 letters within a row indicate significant differences $(P<0.05)$ among the different treatments based on the one-way

3 ANOVA results, followed by the Tukey HSD test results. CK: no thinning; LIT: low intensity thinning; MIT: moderate

4 intensity thinning; HIT: high intensity thinning; SMC: soil moisture content; SOC: soil organic carbon; TN: total

5 nitrogen; TP: total phosphorous; AN: available nitrogen; AP: available phosphorous; AK: available potassium; MBC:

6 microbial biomass carbon; MBN: microbial biomass nitrogen. 
Figure 2

Species richness, vegetation cover, and biomass among the four thinning intensities in the shrub and herb layers.

(A) Species richness in shrub layers. (B) Vegetation cover in shrub layers. (C) Biomass in shrub layers. (D) Species richness in herb layers. (E) Vegetation cover in herb layers. (F) Biomass in herb layers. Values are mean \pm stand error. Different letters indicate significant differences $\left(P^{<} 0.05\right)$ among the four different thinning treatments based on the one-way ANOVA results, followed by the Tukey HSD test results. CK: no thinning; LIT: low intensity thinning; MIT: moderate intensity thinning; HIT: high intensity thinning.
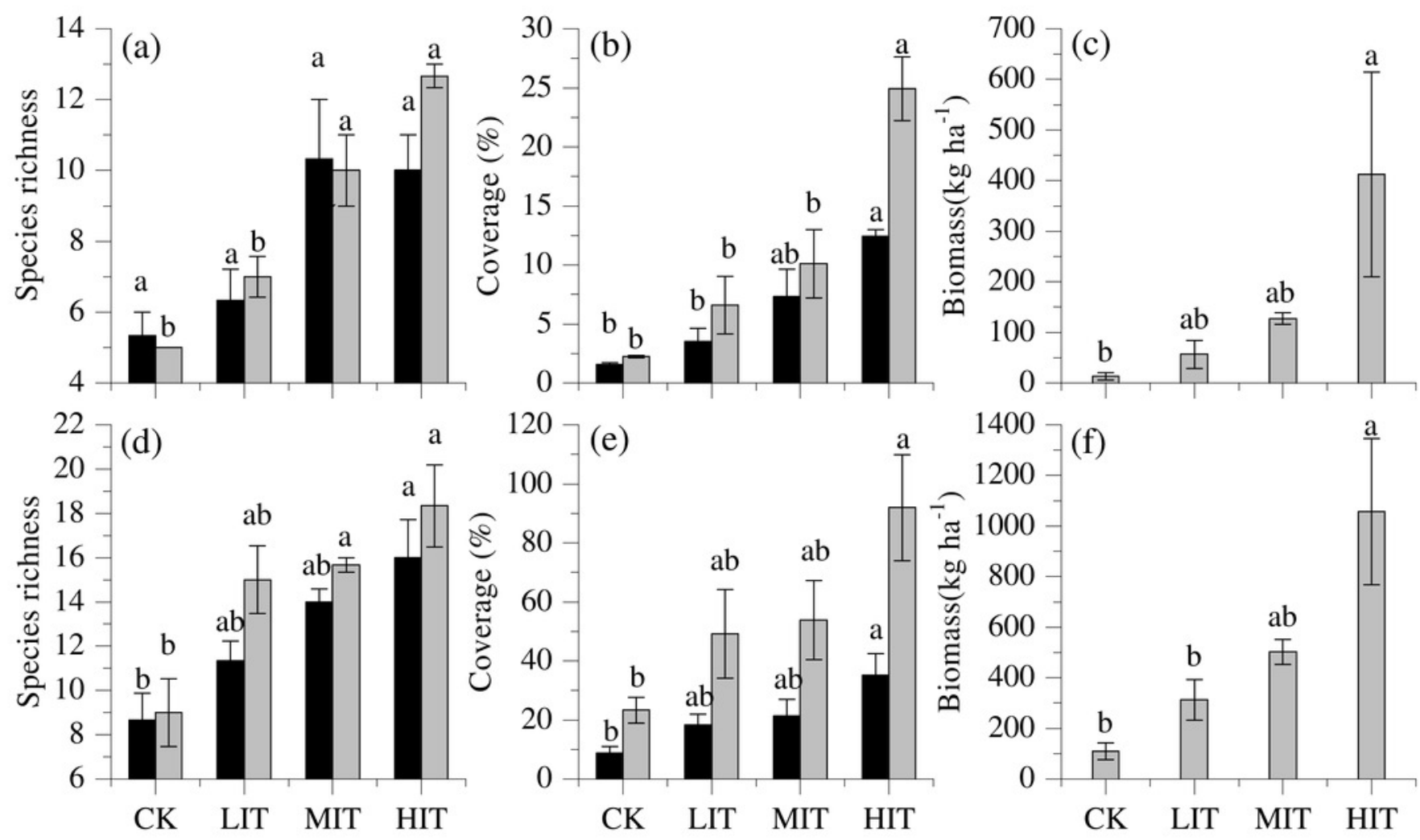

2 years after thinning

Thinning intensity

3 years after thinning 


\section{Table $\mathbf{3}$ (on next page)}

Correlations between understory characteristics and environmental factors. 


\begin{tabular}{|c|c|c|c|c|c|c|c|c|c|c|}
\hline & \multicolumn{4}{|c|}{2 years after thinning } & \multicolumn{6}{|c|}{3 years after thinning } \\
\hline & \multicolumn{2}{|c|}{ Shrub layers } & \multicolumn{2}{|c|}{ Herb layers } & \multicolumn{3}{|c|}{ Shrub layers } & \multicolumn{3}{|c|}{ Herb layers } \\
\hline & $\begin{array}{c}\text { Species } \\
\text { richness }\end{array}$ & Cover & $\begin{array}{l}\text { Species } \\
\text { richness }\end{array}$ & Cover & $\begin{array}{l}\text { Species } \\
\text { richness }\end{array}$ & Cover & Biomass & $\begin{array}{l}\text { Species } \\
\text { richness }\end{array}$ & Cover & Biomass \\
\hline SMC (\%) & $0.030^{*}$ & 0.253 & 0.686 & 0.401 & 0.614 & 0.601 & 0.948 & 0.300 & 0.429 & 0.718 \\
\hline $\mathrm{pH}$ & 0.232 & 0.807 & 0.358 & 0.964 & 0.983 & 0.813 & 0.354 & 0.485 & 0.716 & 0.593 \\
\hline $\mathrm{SOC}\left(\mathrm{g} \mathrm{kg}^{-1}\right)$ & 0.184 & $0.014^{*}$ & $0.040^{*}$ & 0.066 & $0.044^{*}$ & $0.004^{* *}$ & $0.001^{* * *}$ & 0.062 & 0.092 & $0.000^{* * *}$ \\
\hline $\mathrm{TN}\left(\mathrm{g} \mathrm{kg}^{-1}\right)$ & 0.208 & $0.021^{*}$ & 0.092 & 0.176 & 0.068 & $0.014^{*}$ & $0.001^{* * *}$ & 0.142 & 0.267 & $0.000^{* * *}$ \\
\hline $\mathrm{TP}\left(\mathrm{g} \mathrm{kg}^{-1}\right)$ & 0.657 & 0.113 & 0.645 & 0.472 & 0.090 & $0.043^{*}$ & 0.091 & 0.098 & 0.186 & 0.067 \\
\hline $\mathrm{AN}\left(\mathrm{mg} \mathrm{kg}^{-1}\right)$ & 0.408 & 0.181 & 0.807 & 0.770 & 0.273 & 0.229 & 0.198 & 0.066 & 0.641 & 0.127 \\
\hline $\mathrm{AP}\left(\mathrm{mg} \mathrm{kg}^{-1}\right)$ & 0.221 & $0.011^{*}$ & 0.065 & 0.197 & $0.002^{* *}$ & $0.004^{* *}$ & $0.007^{* *}$ & $0.004^{* *}$ & 0.110 & $0.001^{* * *}$ \\
\hline $\mathrm{AK}\left(\mathrm{mg} \mathrm{kg}^{-1}\right)$ & 0.809 & 0.063 & 0.747 & 0.282 & 0.178 & $0.034^{*}$ & 0.205 & 0.392 & 0.184 & 0.168 \\
\hline $\operatorname{Mg}\left(\mathrm{mg} \mathrm{kg}^{-1}\right)$ & 0.897 & 0.729 & 0.877 & 0.418 & 0.674 & 0.706 & 0.332 & 0.476 & 0.167 & 0.527 \\
\hline $\operatorname{Mn}\left(\mathrm{mg} \mathrm{kg}^{-1}\right)$ & 0.528 & 0.613 & 0.820 & 0.648 & 0.419 & 0.407 & 0.955 & 0.329 & 0.311 & 0.905 \\
\hline $\operatorname{MBC}\left(\mathrm{mg} \mathrm{kg}^{-1}\right)$ & 0.717 & 0.746 & 0.681 & 0.690 & 0.457 & 0.931 & 0.597 & 0.119 & 0.747 & 0.867 \\
\hline $\operatorname{MBN}\left(\mathrm{mg} \mathrm{kg}^{-1}\right)$ & 0.180 & 0.170 & 0.687 & 0.366 & 0.105 & 0.259 & 0.744 & 0.083 & 0.366 & 0.438 \\
\hline TD $($ Stem ha-1) & $0.005^{* *}$ & $0.000^{* * *}$ & $0.000^{* * *}$ & $0.005^{* *}$ & $0.000^{* * *}$ & $0.000^{* * *}$ & $0.011^{*}$ & $0.001^{* * *}$ & $0.007^{* *}$ & $0.000^{* * *}$ \\
\hline Aspect & 0.836 & 0.752 & 0.611 & 0.401 & 0.631 & 0.972 & 0.534 & 0.793 & 0.233 & 0.587 \\
\hline Slope $\left(^{\circ}\right)$ & 0.627 & 0.639 & 0.735 & 0.760 & 0.570 & 0.925 & 0.425 & 0.369 & 0.814 & 0.659 \\
\hline Slope position & 0.341 & 0.975 & 0.845 & 0.991 & 0.755 & 0.837 & 0.523 & 1.000 & 0.608 & 0.548 \\
\hline
\end{tabular}

1 Note: ${ }^{*}$ indicates $P<0.05 ;{ }^{* *}$ indicates $P<0.01 ;{ }^{* * *}$ indicates $P<0.001 ;$ TD: Tree density. Other descriptions as in Table 2. 


\section{Table 4 (on next page)}

Indicator species of different treatments based on indicator species analysis (ISA) results. 


\begin{tabular}{|c|c|c|c|c|}
\hline Layers & Treatment & Species & Indicator values & $P$ \\
\hline Shrub & HIT & C. giraldii & 0.511 & 0.049 \\
\hline \multirow[t]{5}{*}{ Herb } & HIT & S. viridis & 1.000 & 0.013 \\
\hline & & D. indica & 1.000 & 0.023 \\
\hline & & P. glanduligera & 0.825 & 0.031 \\
\hline & & A. japonica & 0.553 & 0.030 \\
\hline & & W. japonica & 0.385 & 0.047 \\
\hline
\end{tabular}

1 Note: HIT: high intensity thinning. 
Figure 3

Principal coordinate analysis ( $\mathrm{PCOA}$ ) of the dissimilarities in the understory communities among the different thinning intensities.

CK: no thinning; LIT: low intensity thinning; MIT: moderate intensity thinning; HIT: high intensity thinning.

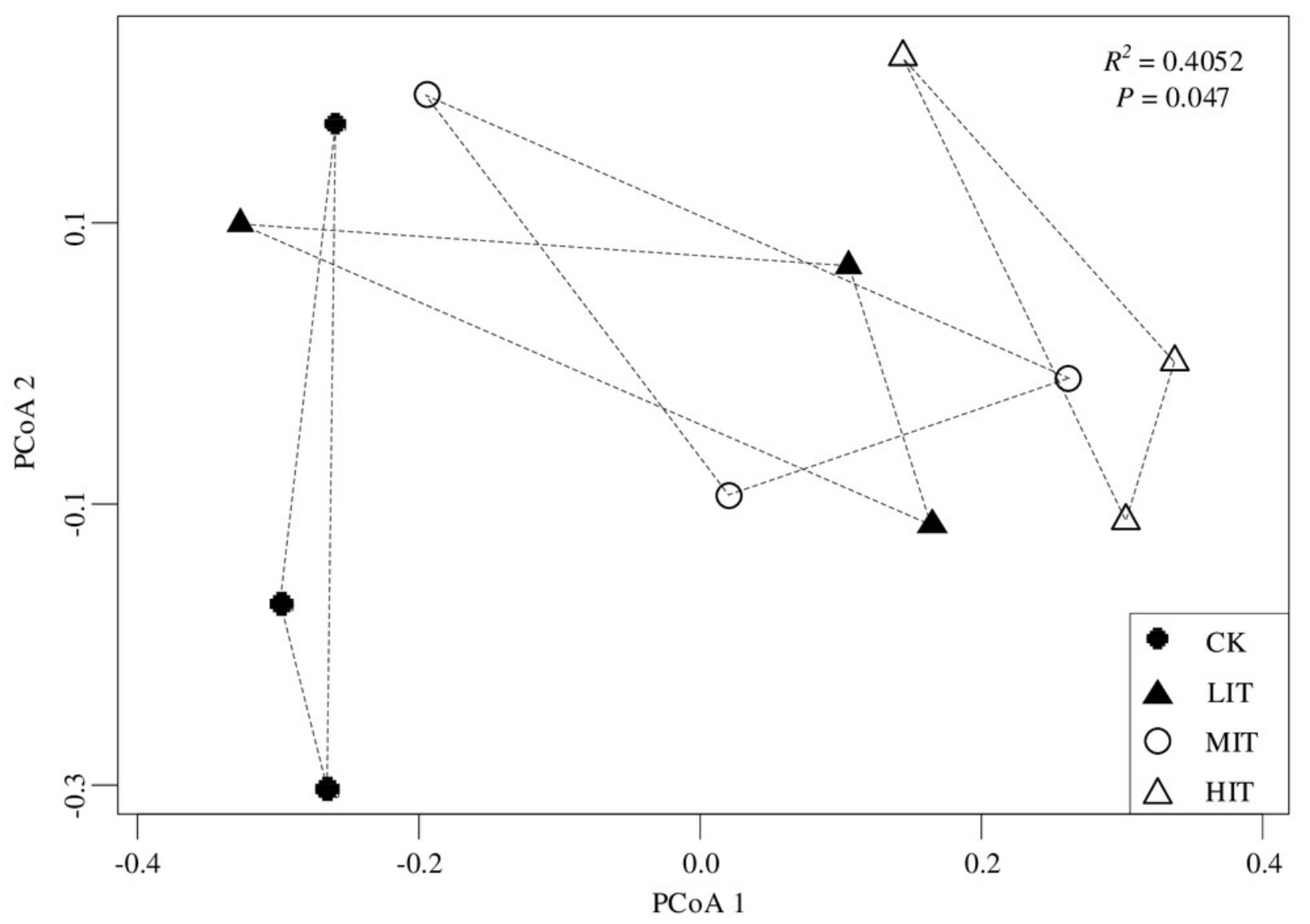




\section{Table 5 (on next page)}

Relationships between the understory communities and the environmental factors as revealed by the Mantel test results. 


\begin{tabular}{|c|c|c|}
\hline Explanatory variables & $R^{2}$ & $P$ \\
\hline TD $($ Stem ha-1) & 0.6752 & $0.005 * *$ \\
\hline Aspect & 0.0322 & 0.862 \\
\hline Slope $\left(^{\circ}\right)$ & 0.0468 & 0.796 \\
\hline Slope Position & 0.8001 & $0.001 * * *$ \\
\hline SMC (\%) & 0.1605 & 0.490 \\
\hline $\mathrm{pH}$ & 0.0807 & 0.724 \\
\hline SOILCN $\left(\mathrm{g} \mathrm{kg}^{-1}\right)$ & 0.6009 & $0.029 *$ \\
\hline $\mathrm{TP}\left(\mathrm{mg} \mathrm{kg}^{-1}\right)$ & 0.3753 & 0.173 \\
\hline SOILA $\left(\mathrm{mg} \mathrm{kg}^{-1}\right)$ & 0.1295 & 0.588 \\
\hline $\mathrm{AK}\left(\mathrm{mg} \mathrm{kg}^{-1}\right)$ & 0.4308 & 0.104 \\
\hline $\operatorname{SOILM}\left(\mathrm{mg} \mathrm{kg}^{-1}\right)$ & 0.6764 & $0.005^{* *}$ \\
\hline $\operatorname{MBC}\left(\mathrm{mg} \mathrm{kg}{ }^{-1}\right)$ & 0.0635 & 0.789 \\
\hline $\operatorname{MBN}\left(\mathrm{mg} \mathrm{kg}^{-1}\right)$ & 0.1053 & 0.536 \\
\hline
\end{tabular}

1 Note: ${ }^{*}$ indicates $P<0.05 ;{ }^{* *}$ indicates $P<0.01 ;{ }^{* * *}$ indicates $P<0.001$; SOILCN: Soil $\mathrm{C}$ and N content; SOILA:

2 Soil available nutrient content; SOILM: Soil Mg and Mn content. Other descriptions as in Table 2. 
Figure 4

Canonical correspondence analysis (CCA) results of the dissimilarities in the understory communities among the different thinning intensities.

CK: no thinning; LIT: low intensity thinning; MIT: moderate intensity thinning; HIT: high intensity thinning. Other descriptions as in Table 2 and 5.

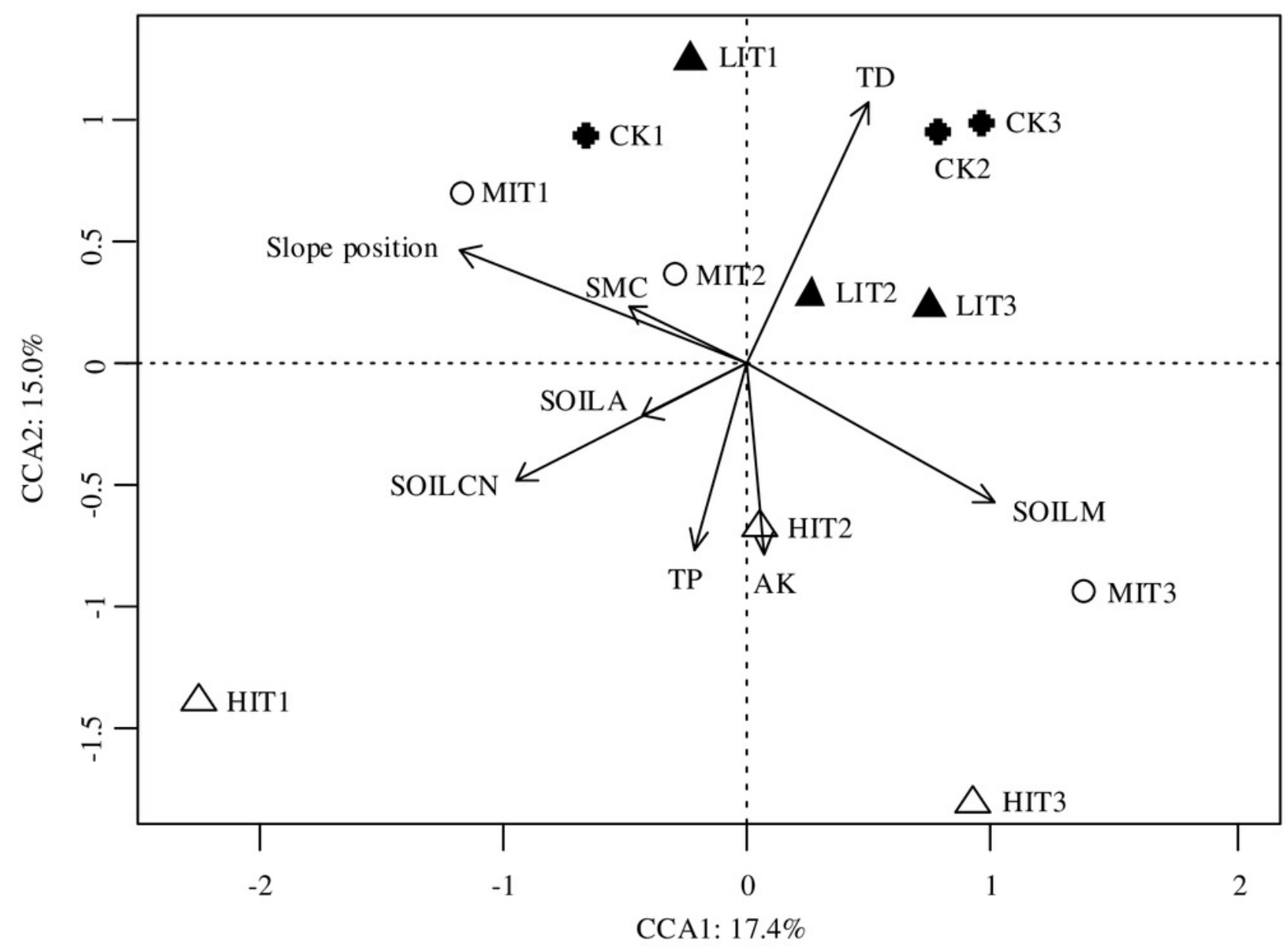

